\title{
Metabolizable energy levels in diets with a fixed nutrient: calorie ratio for free-range broilers
}

\section{Níveis de energia metabolizável com manutenção da relação nutriente:caloria em dietas para frangos de corte tipo caipira}

\author{
Thiago Rodrigues da Silva ${ }^{1}$; Karina Márcia Ribeiro de Souza Nascimento ${ }^{2 *}$; \\ Charles Kiefer ${ }^{2}$; Luanna Lopes Paiva Copat ${ }^{1}$; Henrique Barbosa de Freitas ${ }^{1}$; \\ Natália Ramos Batista Chaves3; Larissa Albuquerque Rosa Silva4; Jeovania \\ Vilhalba Leite ${ }^{5}$; Arnaldo Vitorino Ofiço ${ }^{6}$
}

\section{Highlights}

Adjusting nutrients to the energy level ensures adequate nutrient intake.

The nutrient:calorie ratio improves the feed conversion of free-range broilers.

The nutrient:calorie ratio maintains fat in the carcass for high metabolizable energy.

\section{Abstract}

The present study proposes to examine the effect of dietary levels of metabolizable energy, under a fixed nutrient:calorie ratio, on the production performance; body fat and protein deposition; and carcass characteristics of free-range broilers from 1 to 84 days of age. Nine hundred unsexed chicks were allocated to six treatments in a completely randomized design with six replicates of 25 birds each. Treatments consisted of diets with varying levels of metabolizable energy (2700, 2800, 2900, 3000, 3100 and 3200 $\mathrm{Kcal} \mathrm{ME} / \mathrm{kg}$ of diet) and a fixed proportion of nutrients relative to the energy level according to the nutritional requirements for each rearing phase. Body weight, weight gain, feed intake, feed conversion, production viability, metabolizable energy intake, protein intake, lysine intake, body fat deposition, body protein deposition and carcass characteristics were evaluated. Data were subjected to analysis of variance and, later, to regression analysis. Increasing levels of metabolizable energy, coupled with a fixed nutrient:calorie ratio, reduced feed intake, increased body weight and weight gain, improved feed conversion and did not

1 Drs. in Animal Science, Postgraduate Program in Animal Science, Faculdade de Medicina Veterinária e Zootecnia, FAMEZ, Universidade Federal de Mato Grosso do Sul, UFMS, Campo Grande, MS, Brazil. E-mail: thiagoth_rodrigues@ hotmail.com; lu.paiva.lopes@gmail.com; henrique_barbosa_7@yahoo.com.br

2 Profs., UFMS, Campo Grande, MS, Brazil. E-mail: karina.souza@ufms.br; charles.kiefer@ ufms.br

3 Profa, Instituto Federal de Mato Grosso, IFMT, Alta Floresta Campus, MT, Brazil. E-mail: natalia.chaves@alf.ifmt.edu.br

4 M.e in Animal Science, Postgraduate Program in Animal Science, UFMS, Brazil. E-mail: larissalbuquerquerosa@ gmail.com

5 Animal Scientist, UFMS, Campo Grande, MS, Brazil. E-mail: jeovaniajvl@hotmail.com

6 Prof., Universidade Pedagógica de Maputo, Maputo City, Mozambique. E-mail: oficoarnaldo@hotmail.com

* Author for correspondence

Received: Apr. 19, 2021 - Approved: Aug. 22, 2021 
affect carcass characteristics. In conclusion, adjusting the nutrient supply according to the dietary energy level improves production performance by improving feed conversion, ensuring adequate nutrient intake and preserving fat and protein deposition in the carcass when the metabolizable energy level is raised up to $3200 \mathrm{Kcal} / \mathrm{kg}$ in all rearing stages.

Key words: Abdominal fat. Amino acid intake. Carcass protein. Energy density. Nutritional requirement. Protein intake.

\section{Resumo}

O objetivo do presente estudo foi avaliar os níveis de energia metabolizável, sob uma relação nutriente:caloria fixa, no desempenho produtivo; deposição de gordura e proteína corporal e características de carcaça de frangos de corte tipo caipiras. Foram utilizados novecentos pintainhos não sexados, distribuidos em seis tratamentos em delineamento inteiramente casualizado com seis repetições de 25 aves cada. Os tratamentos consistiram em dietas com diferentes níveis de energia metabolizável (2700, 2800, 2900, 3000, 3100 e 3200 Kcal EM / kg de dieta) e uma proporção fixa de nutrientes em relação ao nível de energia de acordo com as necessidades nutricionais de cada fase de criação. Foram avaliados o peso corporal, ganho de peso, consumo de ração, conversão alimentar, viabilidade criatória, consumo de energia metabolizável, consumo de proteína, consumo de lisina, deposição de gordura corporal, deposição de proteína corporal e características de carcaça. Os dados foram submetidos à análise de variância e posteriormente à análise de regressão. O aumento dos níveis de energia metabolizável juntamente com a manutenção da relação nutriente:caloria reduziu o consumo de ração, aumentou o peso corporal e o ganho de peso, melhorou a conversão alimentar e não afetou as características da carcaça. Em conclusão, o ajuste da oferta de nutrientes de acordo com o nível de energia da dieta melhora o desempenho da produção, melhorando a conversão alimentar, garantindo a ingestão adequada de nutrientes e preservando a deposição de gordura e proteína na carcaça quando o nível de energia metabolizável é elevado até $3200 \mathrm{Kcal} / \mathrm{kg}$ em todas as fases de criação.

Palavras-chave: Densidade energética. Exigência nutricional. Gordura abdominal. Ingestão deaminoácidos. Ingestão de proteína. Proteína de carcaça.

\section{Introduction}

The technological advances of the Brazilian poultry industry have enabled the sector to multiply its production and provide a high-quality product at affordable prices. However, the lack of knowledge of how industrial chickens are raised has drawn the attention of consumers who are concerned about food safety and the welfare of animals farmed in intensive systems (Oliveira, Ferreira, Santana, Brito Junior., \& Mendes, 2015).
Because of its more natural conditions and the generation of a product with distinguished organoleptic characteristics, free-range broiler farming has gained prominence in the poultry industry (Demattê $\&$ Marques, 2011). These birds are reared in a semi-intensive system, where they receive only plant-based feed and diets free of performance enhancers (R. Oliveira et al., 2016).

Few studies have investigated the nutritional requirements of free-range broilers, 
with divergent metabolizable energy (ME) levels that range between $2850 \mathrm{Kcal}$ for the starter phase and $3100 \mathrm{Kcal} / \mathrm{kg}$ of diet for the finisher phase (Globoaves, 2011). However, satisfactory performance has been reported with the use of ME levels close to $3200 \mathrm{Kcal} /$ $\mathrm{kg}$ of diet (Moreira, Santos, Vieira, Tavares, \& Manno, 2012). Therefore, there is a need to elucidate the ideal level of metabolizable energy for slow-growing broilers, which are the lines used in free-range farming systems.

Because metabolizable energy directly affects voluntary feed intake (Abreu \& Lara, 2014) and, consequently, nutrient intake (Scherer, Furlan, Martins, Scapinello, \& Ton, 2011), nutritionists have studied the nutrient:calorie ratio.

The nutrient:calorie ratio considers the energy level and balances all the nutrients in the diet. The objective of formulating diets based on this index is to ensure an adequate nutrient intake, allowing the animal to achieve satisfactory performance and carcass quality without excessive deposition of fat in the carcass (Leeson \& Summer, 2001).

Furthermore, consumers have sought healthier foods (Santos, Palheta, Santos, Nascimento, \& Melo, 2017) and shown decreased interest in meats with a high fat content (Ferreira et al., 2015). In this scenario, the practice of manipulating diet formulations has been highlighted, since their nutritional constitution affects the composition of broiler carcasses (Mendes \& Komiyama, 2011).

The present study was thus undertaken to examine the effect of dietary levels of $M E_{\text {, }}$ under a fixed nutrient:calorie ratio, on the production performance; body fat and protein deposition; and carcass characteristics of free-range broilers from 1 to 84 days of age.

\section{Material and Methods}

The experimental procedures described here were approved by the Ethics Committee on Animal Use (Approval no. 619/2014).

Nine hundred unsexed Naked Neck chicks were allocated to six treatments in a completely randomized design with six replicates of 25 chicks each. Treatments consisted of dietary levels of ME, for all rearing phases (2700, 2800, 2900, 3000, 3100 and $3200 \mathrm{Kcal} \mathrm{ME} / \mathrm{kg}$ ). The experimental period was 84 days, which were divided into three rearing phases, namely, starter (1 to 28 days), grower (29 to 56 days) and finisher (57 to 84 days). Diets were provided in mash form and formulated as proposed by Rostagno et al. (2011) for brown-egg replacement pullets (Tables 1, 2 and 3), containing corn and soybean meal. The nutrient:calorie ratio was established as the percentage of each nutrient divided by the energy level of the diet, based on recommendations for diets with $2900 \mathrm{Kcal} \mathrm{ME} / \mathrm{kg}$. The nutrient:calorie ratio was kept fixed within each period; however, a different proportion was used for each rearing stage, as the nutritional requirements changed throughout the animals' development.

On the first day of housing, six chicks were randomly chosen for slaughter and a subsequent evaluation of body fat and protein deposition. The birds were reared in a conventional shed divided into cages measuring $2.5 \mathrm{~m}^{2}$, equipped with siphon drinkers in the first week, which were then replaced by automatic bell drinkers and trough feeders. All cages contained a brooder with two 100-W incandescent light bulbs to heat the chicks, which were removed at 14 days of age. 
Table 1

Centesimal and nutritional composition of experimental diets from 1 to 28 days of age.

\begin{tabular}{|c|c|c|c|c|c|c|c|}
\hline Ingredient (\%) & & 2700 & 2800 & 2900 & 3000 & 3100 & 3200 \\
\hline Corn & & 63.415 & 65.788 & 68.132 & 67.648 & 63.065 & 58.477 \\
\hline Soybean meal & & 24.120 & 24.980 & 25.868 & 27.285 & 29.403 & 31.520 \\
\hline Soybean oil & & 0.050 & 0.050 & 0.054 & 1.015 & 3.377 & 5.740 \\
\hline Kaolin & & 9.020 & 5.666 & 2.303 & 0.300 & 0.300 & 0.300 \\
\hline Dicalcium phosphate & & 1.670 & 1.727 & 1.795 & 1.856 & 1.927 & 1.997 \\
\hline Calcitic limestone & & 1.032 & 1.072 & 1.107 & 1.145 & 1.174 & 1.205 \\
\hline Salt & & 0.376 & 0.392 & 0.406 & 0.421 & 0.437 & 0.454 \\
\hline DL-methionine & & 0.118 & 0.123 & 0.129 & 0.135 & 0.145 & 0.156 \\
\hline L-lysine $\mathrm{HCl} 99 \%$ & & 0.049 & 0.053 & 0.055 & 0.045 & 0.023 & 0.000 \\
\hline Vitamin supplement & & 0.100 & 0.100 & 0.100 & 0.100 & 0.100 & 0.100 \\
\hline \multirow[t]{2}{*}{ Mineral supplement } & & 0.050 & 0.050 & 0.050 & 0.050 & 0.050 & 0.050 \\
\hline & $\begin{array}{c}\text { Nutrient:calorie } \\
(\%: K c a l / k g)\end{array}$ & & & & & & \\
\hline $\mathrm{ME}, \mathrm{Kcal} / \mathrm{kg}$ & - & 2700 & 2800 & 2900 & 3000 & 3100 & 3200 \\
\hline Crude protein, \% & 6.01 & 16.227 & 16.828 & 17.429 & 18.030 & 18.631 & 19.232 \\
\hline Dig. met + cys., \% & 0.21 & 0.567 & 0.588 & 0.609 & 0.630 & 0.651 & 0.672 \\
\hline Digestible methionine, \% & 0.13 & 0.351 & 0.364 & 0.377 & 0.390 & 0.403 & 0.416 \\
\hline Digestible lysine, \% & 0.29 & 0.783 & 0.812 & 0.841 & 0.870 & 0.899 & 0.928 \\
\hline Calcium, \% & 0.32 & 0.864 & 0.896 & 0.928 & 0.960 & 0.992 & 1.024 \\
\hline Available phosphorus, \% & 0.15 & 0.405 & 0.420 & 0.435 & 0.450 & 0.465 & 0.480 \\
\hline Sodium, \% & 0.06 & 0.162 & 0.168 & 0.174 & 0.180 & 0.186 & 0.192 \\
\hline
\end{tabular}

Provides per kg of diet - Mineral supplement: 11.00 mg zinc; 3.04 mg pantothenic acid; 0.22 mg iodine; 0.06 mg selenium; 90 mg choline; 8.48 mg iron; 2.64 mg copper; 15.15 mg manganese, Provides per kg of diet - Vitamin supplement: 2400 IU vitamin A; 480 IU vitamin D3; 0.32 mg vitamin $\mathrm{K} 3 ; 0.51 \mathrm{mg}$ vitamin $\mathrm{B} 1 ; 1.38 \mathrm{mg}$ vitamin $\mathrm{B} 2 ; 0.64 \mathrm{mg}$ vitamin $\mathrm{B} 6 ; 2.88 \mathrm{mg}$ vitamin $B 12 ; 3.00$ mg vitamin $E ; 7.12$ mg niacin. Diets formulated according to the nutritional requirements recommended by Rostagno et al. (2011) for brown-egg replacement pullers, with a fixed nutrient:calorie ratio.

Non-used pine shavings were used as litter (8-cm high). Relative humidity and maximum and minimum temperatures were recorded daily at $07 \mathrm{h00}$ and $17 \mathrm{h00}$ by digital thermohygrometers, which were installed around the height of the birds.
The birds were fed freely so that there were no empty feeders and the drinkers were washed twice a day to renew the water. As soon as they gained access to the paddocks, the chickens were released at $07 \mathrm{h00}$ and gathered in the inner area of the shed at $17 \mathrm{~h} 00$. 
Table 2

Centesimal and nutritional composition of experimental diets in the finisher phase (29 to 56 days).

\begin{tabular}{|lccccccc}
\hline Ingredient (\%) & 2700 & 2800 & 2900 & 3000 & 3100 & 3200 \\
\hline Corn & & 66.334 & 68.806 & 71.263 & 70.606 & 70.589 & 66.297 \\
Soybean meal & & 19.926 & 20.645 & 21.394 & 22.669 & 23.854 & 25.748 \\
Soybean oil & & 0.050 & 0.050 & 0.050 & 1.115 & 1.957 & 4.265 \\
Kaolin & 10.784 & 7.500 & 4.182 & 2.404 & 0.300 & 0.300 \\
\hline Dicalcium phosphate & & 1.462 & 1.515 & 1.569 & 1.626 & 1.682 & 1.744 \\
Calcitic limestone & 0.884 & 0.917 & 0.950 & 0.979 & 1.009 & 1.035 \\
\hline Salt & & 0.329 & 0.329 & 0.356 & 0.369 & 0.381 & 0.397 \\
DL-methionine & 0.046 & 0.048 & 0.049 & 0.054 & 0.058 & 0.066 \\
L-lysine HCl 99\% & & 0.036 & 0.038 & 0.039 & 0.029 & 0.021 & 0.000 \\
Vitamin supplement & & 0.100 & 0.100 & 0.100 & 0.100 & 0.100 & 0.100 \\
\hline Mineral supplement & & 0.050 & 0.050 & 0.050 & 0.050 & 0.050 & 0.050 \\
& Nutrient:calorie & & & & & & \\
ME, Kcal/kg & & & & & & & \\
Crude protein, \% & - & 2700 & 2800 & 2900 & 3000 & 3100 & 3200 \\
\hline Dig. met + cys., \% & 5.36 & 14.480 & 15.010 & 15.550 & 16.080 & 16.620 & 17.140 \\
\hline Digestible methionine, \% & 0.09 & 0.243 & 0.252 & 0.261 & 0.270 & 0.279 & 0.288 \\
\hline Digestible lysine, \% & 0.09 & 0.243 & 0.252 & 0.261 & 0.270 & 0.279 & 0.288 \\
Calcium, \% & 0.25 & 0.675 & 0.700 & 0.725 & 0.750 & 0.775 & 0.800 \\
\hline Available phosphorus, \% & 0.28 & 0.756 & 0.784 & 0.812 & 0.840 & 0.868 & 0.896 \\
\hline Sodium, \% & 0.13 & 0.351 & 0.364 & 0.377 & 0.390 & 0.403 & 0.416 \\
\hline & 0.05 & 0.135 & 0.140 & 0.145 & 0.150 & 0.155 & 0.160 \\
\hline
\end{tabular}

Provides per $\mathrm{kg}$ of diet - Mineral supplement: $11.00 \mathrm{mg}$ zinc; $3.04 \mathrm{mg}$ pantothenic acid; $0.22 \mathrm{mg}$ iodine; $0.06 \mathrm{mg}$ selenium; $90 \mathrm{mg}$ choline; $8.48 \mathrm{mg}$ iron; $2.64 \mathrm{mg}$ copper; $15.15 \mathrm{mg}$ manganese. Provides per kg of diet - Vitamin supplement: 2400 IU vitamin $A ; 480$ IU vitamin D3; $0.32 \mathrm{mg}$ vitamin $\mathrm{K} 3 ; 0.51 \mathrm{mg}$ vitamin $\mathrm{B} 1 ; 1.38 \mathrm{mg}$ vitamin $\mathrm{B} 2 ; 0.64 \mathrm{mg}$ vitamin $\mathrm{B} 6 ; 2.88 \mathrm{mg}$ vitamin $B 12 ; 3.00 \mathrm{mg}$ vitamin $\mathrm{E} ; 7.12 \mathrm{mg}$ niacin. Diets formulated according to the nutritional requirements recommended by Rostagno et al. (2011) for brown-egg replacement pullers, with a fixed nutrient:calorie ratio.

Birds, feed and orts were weighed weekly. Body weight, weight gain, feed intake, feed conversion and production viability were measured. Feed intake was calculated as the difference between the amount of feed supplied and orts, at the end of each phase. Weight gain was determined as the difference between final and initial weights, at 28, 56 and
84 days. Production viability was calculated as the percentage of live animals relative to the number of birds housed initially (100 - (\% mortality)). Feed conversion was determined by dividing feed intake by weight gain. Feed intake was corrected for mortality as proposed by Sakomura and Rostagno (2017). 
Table 3

Centesimal and nutritional composition of experimental diets in the finisher phase (57 to 84 days)

\begin{tabular}{|c|c|c|c|c|c|c|c|}
\hline Ingredient (\%) & & 2700 & 2800 & 2900 & 3000 & 3100 & 3200 \\
\hline Corn & & 68.926 & 71.479 & 74.017 & 76.603 & 76.508 & 72.954 \\
\hline Soybean meal & & 16.005 & 16.604 & 17.235 & 17.778 & 19.274 & 20.551 \\
\hline Soybean oil & & 0.050 & 0.050 & 0.050 & 0.050 & 0.851 & 3.024 \\
\hline Kaolin & & 12.303 & 9.054 & 5.797 & 2.568 & 0.300 & 0.300 \\
\hline Dicalcium phosphate & & 1.121 & 1.160 & 1.204 & 1.243 & 1.285 & 1.335 \\
\hline Calcitic limestone & & 1.040 & 1.081 & 1.118 & 1.159 & 1.194 & 1.227 \\
\hline Salt & & 0.310 & 0.323 & 0.332 & 0.345 & 0.357 & 0.371 \\
\hline DL-methionine & & 0.067 & 0.070 & 0.071 & 0.075 & 0.074 & 0.087 \\
\hline L-lysine $\mathrm{HCl} 99 \%$ & & 0.028 & 0.028 & 0.027 & 0.030 & 0.007 & 0.000 \\
\hline Vitamin supplement & & 0.100 & 0.100 & 0.100 & 0.100 & 0.100 & 0.100 \\
\hline \multirow[t]{2}{*}{ Mineral supplement } & & 0.050 & 0.050 & 0.050 & 0.050 & 0.050 & 0.050 \\
\hline & $\begin{array}{c}\text { Nutrient:calorie } \\
(\%: K c a l / k g)\end{array}$ & & & & & & \\
\hline $\mathrm{ME}, \mathrm{Kcal} / \mathrm{kg}$ & - & 2700 & 2800 & 2900 & 3000 & 3100 & 3200 \\
\hline Crude protein, \% & 4.77 & 12.879 & 13.356 & 13.833 & 14.310 & 14.787 & 15.264 \\
\hline Dig. met + cys., \% & 0.17 & 459.000 & 0.476 & 0.493 & 0.510 & 0.527 & 0.544 \\
\hline Digestible methionine, \% & 0.1 & 0.270 & 0.280 & 0.290 & 0.300 & 0.310 & 0.320 \\
\hline Digestible lysine, \% & 0.21 & 0.567 & 0.588 & 0.609 & 0.630 & 0.651 & 0.672 \\
\hline Calcium, \% & 0.27 & 0.729 & 0.756 & 0.783 & 0.810 & 0.837 & 0.864 \\
\hline Available phosphorus, \% & 0.11 & 0.297 & 0.308 & 0.319 & 0.330 & 0.341 & 0.352 \\
\hline Sodium, \% & 0.05 & 0.135 & 0.140 & 0.145 & 0.150 & 0.155 & 0.160 \\
\hline
\end{tabular}

Provides per kg of diet - Mineral supplement: 11.00 mg zinc; 3.04 mg pantothenic acid; 0.22 mg iodine; 0.06 mg selenium; 90 mg choline; 8.48 mg iron; 2.64 mg copper; 15.15 mg manganese. Provides per kg of diet - Vitamin supplement: 2400 IU vitamin A; 480 IU vitamin D3; 0.32 mg vitamin $\mathrm{K} 3 ; 0.51 \mathrm{mg}$ vitamin $\mathrm{B} 1 ; 1.38 \mathrm{mg}$ vitamin $\mathrm{B} 2 ; 0.64 \mathrm{mg}$ vitamin $\mathrm{B} 6 ; 2.88 \mathrm{mg}$ vitamin $B 12 ; 3.00 \mathrm{mg}$ vitamin $\mathrm{E} ; 7.12 \mathrm{mg}$ niacin. Diets formulated according to the nutritional requirements recommended by Rostagno et al. (2011) for brown-egg replacement pullers, with a fixed nutrient:calorie ratio.

The birds were vaccinated against the Newcastle and infectious bursal diseases by eye drop application on the seventh day of life and against fowl pox by puncturing the wing membrane at 28 days. From 28 days of age, the chickens were allowed free access to the paddocks, which consisted of an area of 20 $\mathrm{m}^{2}$ lexperimental unit.
At 28,56 and 84 days of age, one bird with the average weight of the replicate ( $\pm 10 \%)$ was selected, identified with a numbered ring on one of the feet and fasted for approximately $8 \mathrm{~h}$ to be subsequently stunned by cervical displacement, prior to bleeding. After the 84-day-old chickens were scalded and plucked, their carcasses were eviscerated and 
weighed; the breast, back, wings, drumstick and thigh cuts were extracted; and abdominal fat was weighed. Cut yields and fat percentage were determined relative to carcass weight.

All carcasses were ground without the neck and feet and then stored separately in labeled plastic bags. Subsequently, samples represented by duplicates containing $70 \mathrm{~g}$ of meat were collected, placed in Petri dishes and oven-dried at $105^{\circ} \mathrm{C}$ for $72 \mathrm{~h}$. After drying, the samples were ground through a ball mill and processed for analyses of dry matter, crude protein and ether extract, following the methodology developed by Silva and Queiroz (2002).
Data were subjected to analysis of variance and later to regression analysis using SAS software version 9.1, with differences considered significant when $\mathrm{P}<0.05$.

\section{Results and Discussion}

The recorded minimum and maximum temperature and relative humidity means are presented for the different phases in the period from 1 to 84 days (Table 4).

\section{Table 4}

Temperature and relative humidity recorded during the experimental period

\begin{tabular}{|ccccc|} 
& \multicolumn{2}{c}{ Temperature $\left(\mathrm{C}^{\circ}\right)$} & \multicolumn{2}{c|}{ Moisture (\%) } \\
\cline { 2 - 5 } Period & Minimum & Maximum & Minimum & Maximum \\
\hline 1 to 28 days & 21.70 & 30.70 & 52.64 & 81.62 \\
29 to 56 days & 23.91 & 31.62 & 59.87 & 85.87 \\
57 to 84 days & 25.96 & 32.66 & 55.84 & 82.46 \\
\hline
\end{tabular}

The minimum and maximum temperatures recorded during the experimental period indicated that the birds were under hot conditions, mainly in the periods of 29 to 56 and 57 to 84 days of age, if we consider that Globoaves (2011) recommends that ambient temperature for free-range Naked Neck chickens should be $32{ }^{\circ} \mathrm{C}$ in the first week and then reduced by approximately $3^{\circ} \mathrm{C}$ per week until reaching $21^{\circ} \mathrm{C}$ in the fourth rearing week. The average relative humidity remained within the range of 50 to $70 \%$ described as adequate by Baracho, Nääs, Nascimento, Cassiano and Oliveira (2011).

Although the ambient temperature values were unfavorable to the farming of those animals, bird performance was not compromised. This was possibly because the chickens belonged to the Naked Neck line, whose lack of feathers in the neck region provides better adaptation to hot environments, preserving production performance. 
Some studies have shown that Naked Neck lines have the $\mathrm{Na}$ gene, whose expression implies mainly absence of feathers on the neck and other body areas (Wasti, Sah, \& Misha, 2020).

Because feathers can work as a thermal insulating agent and promote an increase in body temperature (Melo et al., 2016), their reduction may favor body heat dissipation and reduce the negative influence of high ambient temperatures, as observed by Santos et al. (2012a). Those authors found lower variations in cloacal temperature in Naked Neck chicks as compared with featherless birds, which reduced stress from high temperatures and favored production indices.

From 1 to 28 days, there was no significant effect $(P>0.05)$ of ME levels, under a fixed nutrient:calorie ratio, on the performance variables (Table 5). The exception was feed conversion, which decreased linearly $(y=$ $\left.-0.00065190 x+3.63340 ; R^{2}=0.9031\right)$ as the dietary ME level was increased.

The increase in the $\mathrm{ME}$ content of diets associated with a fixed nutrient:calorie ratio did not change the performance of freerange chickens from 1 to 28 days of age. This shows that, due to the immaturity of the digestive tract, mainly due to inefficiency in lipase production, younger birds are less able to regulate feed intake through energy intake (Maiorka et al., 2004). Santos et al. (2012b) worked with energy levels between 3100 and $3300 \mathrm{Kcal} / \mathrm{kg}$ in diets for Barré French freerange broilers and did not observe significant differences for body weight, weight gain or feed intake in the period from 1 to 28 days.

Although neither feed intake nor weight gain differed significantly from 1 to 28 days, feed conversion improved linearly as the dietary energy level was increased. This might have been a response to the increased amount of energy provided by the inclusion of soybean oil, which reduced the heat increment due to the decreased expenditure of energy incurred in the digestive processes. As a result, energy metabolisability was increased (Sakomura et al., 2004).

In this context, it is understood that the use of lipid sources helps to reduce heat increment and influences the rate of passage of digesta, possibly improving nutrient digestibility and ultimately improving production performance.

From 1 to 56 and 1 to 84 days, the increasing $\mathrm{ME}$ levels resulting from the nutritional adjustment led to a linear increase $(P<0.05)$ in body weight $(y=0.47633 x+$ 837.78889; $R^{2}=0.9729$ and $y=0.64305 x+$ 1651.84286; $R^{2}=0.9476$ ) and weight gain $\left(y=0.47633 x+837.78889 ; R^{2}=0.9729\right.$ and $\left.y=0.64305 x+1651.84286 ; R^{2}=0.9483\right)$, respectively.

Feed intake decreased linearly $(\mathrm{y}=$ $-0.00079714 x+7.61735 ; R^{2}=0.9714$ and $y=$ $\left.-0.00178 x+16.14217 ; R^{2}=0.9248\right)$, whereas ME intake increased linearly $(y=0.05124 x+$ $125.90317 ; R^{2}=0.9726$ and $y=0.06733 x+$ 183.03333; $\left.R^{2}=0.9322\right)(P<0.05)$.

The higher body weight and weight gain of the free-range chickens observed at 56 and 84 days of age are possibly related to the maturation of the gastrointestinal tract (Santos et al., 2012b), demonstrating that older birds are more effective in producing lipase, trypsin, biliary secretions and amylase, which improve the absorption of ingested nutrients. These, in turn, are diverted to organ formation and muscle development. 
Table 5

Performance and body protein and fat deposition in free-range broilers fed diets with different levels of metabolizable energy and a fixed nutrient:calorie ratio.

\begin{tabular}{|c|c|c|c|c|c|c|c|c|}
\hline \multirow[b]{2}{*}{ Variable } & \multicolumn{8}{|c|}{ Energy level (Kcal/kg) } \\
\hline & 2700 & 2800 & 2900 & 3000 & 3100 & 3200 & P-value & CV (\%) \\
\hline & \multicolumn{8}{|c|}{1 to 28 days } \\
\hline IBW, g & 44 & 44 & 44 & 44 & 44 & 45 & - & - \\
\hline BW, g NS & 831 & 831 & 859 & 873 & 885 & 914 & 0.6840 & 11.22 \\
\hline WG, g NS & 792 & 787 & 815 & 829 & 841 & 869 & 0.6635 & 11.51 \\
\hline $\mathrm{Fl}$, g/birdNS & 1453 & 1462 & 1412 & 1353 & 1384 & 1324 & 0.3059 & 8.53 \\
\hline FC, g:g* & 1.84 & 1.86 & 1.74 & 1.64 & 1.66 & 1.53 & $<0.0001$ & 4.30 \\
\hline PV, \% NS & 98.67 & 97.97 & 98.00 & 98.00 & 95.97 & 98.00 & 0.7381 & 3.11 \\
\hline MEI, Kcal/dayNS & 140.10 & 146.16 & 146.27 & 144.92 & 153.25 & 151.37 & 0.5252 & 8.51 \\
\hline CPI, g/dayNS & 8.42 & 8.78 & 8.79 & 8.71 & 9.21 & 9.10 & 0.5259 & 8.55 \\
\hline Lysl, g/dayNS & 0.41 & 0.42 & 0.42 & 0.42 & 0.44 & 0.44 & 0.5533 & 8.72 \\
\hline BFD, g/birdNS & 9.33 & 8.71 & 9.38 & 8.86 & 9.50 & 10.53 & 0.0647 & 8.75 \\
\hline \multirow[t]{2}{*}{ BPD, g/birdNS } & 10.37 & 11.40 & 11.28 & 12.64 & 12.35 & 10.96 & 0.1608 & 8.74 \\
\hline & \multicolumn{8}{|c|}{1 to 56 days } \\
\hline$B W, g^{*}$ & 2188 & 2202 & 2257 & 2304 & 2348 & 2424 & $<0.0001$ & 3.63 \\
\hline$W G, g^{*}$ & 2144 & 2158 & 2213 & 2260 & 2304 & 2380 & $<0.0001$ & 3.63 \\
\hline $\mathrm{Fl}, \mathrm{g} / \mathrm{bird}^{*}$ & 5458 & 5360 & 5343 & 5225 & 5168 & 5040 & $<0.0001$ & 3.08 \\
\hline $\mathrm{FC}, \mathrm{g} / \mathrm{g}^{*}$ & 2.55 & 2.49 & 2.42 & 2.31 & 2.25 & 2.12 & $<0.0001$ & 2.29 \\
\hline PV, \% NS & 98.67 & 97.31 & 97.33 & 97.33 & 95.31 & 98 & 0.6582 & 3.49 \\
\hline MEI, Kcal/day* & 263.17 & 268.01 & 276.71 & 279.9 & 286.08 & 287.98 & $<0.0001$ & 3.15 \\
\hline CPI, g/day** & 14.56 & 14.84 & 16.01 & 16.86 & 15.83 & 15.93 & 0.0002 & 3.98 \\
\hline Lysl, g/day NS & 0.20 & 0.21 & 0.21 & 0.21 & 0.22 & 0.22 & 0.5929 & 8.76 \\
\hline BFD, g/birdNS & 11.75 & 10.41 & 11.37 & 10.67 & 11.00 & 13.81 & 0.1433 & 13.25 \\
\hline \multirow[t]{2}{*}{ BPD, g/birdNS } & 13.79 & 12.88 & 14.72 & 13.63 & 11.77 & 12.73 & 0.2349 & 12.26 \\
\hline & \multicolumn{8}{|c|}{1 to 84 days } \\
\hline$B W, g^{*}$ & 3448 & 3494 & 3549 & 3630 & 3644 & 3793 & 0.0009 & 3.63 \\
\hline$W G, g^{*}$ & 3404 & 3450 & 3505 & 3586 & 3600 & 3748 & 0.0008 & 5.04 \\
\hline Fl, g/bird* & 11399 & 10991 & 11046 & 10811 & 10691 & 10379 & 0.0001 & 3.87 \\
\hline $\mathrm{FC}, \mathrm{g} / \mathrm{g}^{*}$ & 3.35 & 3.19 & 3.16 & 3.02 & 2.97 & 2.77 & $<0.0001$ & 2.96 \\
\hline PV, \%NS & 98.00 & 96.64 & 97.33 & 97.33 & 93.97 & 94.97 & 0.5379 & 4.54 \\
\hline MEI, Kcal/day* & 366.39 & 366.39 & 381.35 & 386.12 & 394.54 & 395.39 & $<0.0001$ & 3.92 \\
\hline CPI, g/day** & 18.82 & 18.85 & 20.06 & 20.75 & 20.28 & 20.32 & 0.0370 & 4.16 \\
\hline Lysl, g/day* & 0.67 & 0.68 & 0.70 & 0.70 & 0.72 & 0.72 & 0.2427 & 6.27 \\
\hline BFD, g/birdNS & 13.02 & 13.19 & 14.26 & 15.40 & 14.73 & 15.22 & 0.2875 & 15.14 \\
\hline BPD, g/birdNS & 13.22 & 12.92 & 12.50 & 12.36 & 12.37 & 13.54 & 0.9489 & 19.65 \\
\hline
\end{tabular}

IBW: initial body weight; BW: body weight, WG: weight gain, Fl: feed intake, FC: feed conversion, PV: production viability, MEI: metabolizable energy intake, CPI: crude protein intake, Lysl: lysine intake, BFD: body fat deposition, BPD: body protein deposition. *Linear effect $(\mathrm{P}<0.05) .{ }^{*}$ Quadratic effect $(\mathrm{P}<0,05)$. CV: coefficient of variation. 
Moreover, because weight gain and body weight are dependent on nutrient intake (Scherer et al., 2011), the fixed proportion between energy and nutrient levels in the diet provided increases in both variables.

From 1 to 56 and 1 to 84 days, feed intake decreased as the dietary energy levels were raised. This response can be explained by the higher daily ME intake. Birds are known to consume a certain amount of feed to meet primarily their energy requirement (Bertechini, 2013), and variations in the dietary energy level prompt changes in feed intake, thus influencing the intake of all nutrients (Mirzaee, Torki, \& Habibian, 2014).

Crude protein intake $\left(y=-0.00001731 x^{2}\right.$ $+0.10519 x-143.46746 ; R^{2}=0.7746$ and $y=$ $-0.00001199 x^{2}+0.07430 x-94.66467 ; R^{2}=$ $0.8295)$ responded quadratically $(P<0.05)$ as the dietary energy levels were increased from 2700 to $3200 \mathrm{Kcal} / \mathrm{kg}$ (from 1 to 56 and 1 to 84 days of age, respectively). However, digestible lysine intake was not affected in any of the periods.

Crude protein intake responded quadratically from 1 to 56 and 1 to 84 days of age, with the highest values observed in the group fed the diets formulated with 3000 $\mathrm{Kcal}$, in both phases. The decrease in crude protein intake was possibly a consequence of the reduction in feed intake. However, bird performance was not compromised, as the uptake of digestible amino acids was increased due to the maintenance of the nutrient:calorie ratio.
Based on the developed equations, under a fixed nutrient:calorie ratio, the estimated dietary levels of ME to provide the highest intake of crude protein in the periods of 1 to 56 and 1 to 84 days would be 3038 and $3098 \mathrm{Kcal} / \mathrm{kg}$, respectively

From 1 to 56 and 1 to 84 days, the ME level of the diet under a fixed nutrient:calorie ratio influenced feed conversion $(P<0.05)$, as shown by the following linear equations: $y=$ $-0.00084333 x+4.84144 ; R^{2}=0.9726$ and $y=$ $-0.00106 x+6.19187 ; R^{2}=0.9322$. According to the equations, feed conversion improved as the dietary energy level was increased.

Feed conversion improved linearly from 1 to 56 and 1 to 84 days of age, because the increasing dietary energy levels led to a reduction in feed intake and an increase in weight gain, in those rearing periods.

The lower feed intake might have favored the action of digestive enzymes, considering that larger volumes of digesta in the digestive tract imply decreased enzyme efficiency on the digesta (Dourado, Barbosa, \& Sakomura, 2014; Angel \& Sorbara, 2014), which consequently limits nutrient absorption. Within biological limits, diets with higher energy contents are better in terms of feed conversion, given the reduced need for feed to meet the bird's energy requirements (Ferreira et al., 2015).

Production viability was in line with the species and rearing system tested in this study in all evaluated periods, corroborating the results presented by Litz, Carvalho, Fernandes, Martins and Fagundes (2014), who stated that energy levels do not interfere with mortality. 
There was no significant effect $(P>0.05)$ of $\mathrm{ME}$ levels under a fixed nutrient:calorie ratio on body fat or protein deposition.The increasing levels of ME in the diet associated with a fixed nutrient:calorie ratio provided the same body fat and protein deposition values in all rearing phases, demonstrating that adjusting the nutrient level of the diet according to its energy content results in a balanced deposition of fat and protein in the carcass.

Considering the effect of energy levels on nutrient intake, increasing the energy content of a diet without adjusting its crude protein, amino acid, vitamin and mineral levels results in excess fat deposition in the carcass (Macari \& Maiorka, 2017). Thus, the nutrient:calorie ratio must be adjusted to preserve the balance between protein and fat deposition, as described by Litz et al. (2014). Additionally, ensuring adequate energy intake reduces abdominal fat deposition, whereas an adequate intake of crude protein is required for lean tissue deposition. However, surplus protein may be deposited as adipose tissue, influencing the carcass deposition (Jordão et al., 2012).

At 84 days of age, the carcass characteristics of the free-range broilers (Table 6) did not change in response to the dietary energy levels under a fixed nutrient:calorie ratio when the ME levels in the diet were increased from 2700 to $3200 \mathrm{Kcal} / \mathrm{kg}$.
The unchanged breast weight across the treatments demonstrates the influence of lysine intake. As mentioned by Rosa etal. (2014), adequate digestible lysine concentrations in the diet are indicative of improved amino acid balance, which favors protein deposition in the breast muscle, since this amino acid is utilized almost exclusively with this purpose (Ajinomoto, 2012).

In conclusion, adjusting the nutrient levels according to the energy content of the diet improves production performance as a result of improved feed conversion, ensuring adequate nutrient intake and preserving fat and protein deposition in the carcass when the metabolizable energy level is raised up to $3200 \mathrm{Kcal} / \mathrm{kg}$ in all rearing stages.

\section{Acknowledgments}

The authors thank the National Council for Scientific and Technological Development (CNPq) and the Federal University of Mato Grosso do Sul (UFMS) for the financial support. This study was financed in part by the Coordenação de Aperfeiçoamento de Pessoal de Nível Superior - Brasil (CAPES) - Finance Code 001. 
Table 6

Carcass characteristics of 84-day-old free-range broilers fed diets with different levels of metabolizable energy and a fixed nutrient:calorie ratio.

\begin{tabular}{lcccccccc} 
& \multicolumn{7}{c}{ Energy level (Kcal/kg) } \\
\cline { 2 - 9 } Variable & 2700 & 2800 & 2900 & 3000 & 3100 & 3200 & P-value & CV (\%) \\
\hline Carcass, g & 2384 & 2230 & 2466 & 2594 & 2495 & 2540 & 0.0824 & 8.75 \\
\hline Breast, g & 754.50 & 691.17 & 771.83 & 803.00 & 799.67 & 783.83 & 0.0756 & 8.82 \\
\hline Thigh and drumstick, g & 74.73 & 70.22 & 75.85 & 81.63 & 74.80 & 81.50 & 0.2978 & 12.48 \\
\hline Wing, g & 263.50 & 235.33 & 271.67 & 279.83 & 252.17 & 282.17 & 0.1240 & 12.04 \\
\hline Back, g & 608.17 & 607.50 & 653.67 & 681.50 & 671.50 & 645.00 & 0.2392 & 9.89 \\
\hline Neck, g & 98.00 & 90.83 & 97.67 & 93.67 & 89.33 & 87.17 & 0.9768 & 29.84 \\
\hline Feet, g & 109.67 & 95.33 & 109.50 & 114.50 & 98.33 & 110.00 & 0.5151 & 18.74 \\
\hline Head, g & 81.17 & 76.50 & 79.17 & 81.00 & 74.17 & 86.50 & 0.8518 & 21.01 \\
\hline Fat, g & 155.00 & 156.17 & 194.00 & 168.42 & 178.24 & 178.08 & 0.8679 & 35.19 \\
Carcass, \% & 69.78 & 67.520 & 69.860 & 69.490 & 69.470 & 68.790 & 0.3355 & 2.85 \\
\hline Breast, \% & 31.66 & 31.05 & 31.30 & 31.02 & 32.02 & 30.90 & 0.7341 & 4.55 \\
\hline Thigh and drumstick, \% & 31.35 & 31.33 & 30.72 & 31.98 & 29.98 & 31.99 & 0.4347 & 5.43 \\
Wing, \% & 11.07 & 10.53 & 11.02 & 10.76 & 10.11 & 11.08 & 0.1824 & 6.82 \\
\hline Back, \% & 25.49 & 27.30 & 26.51 & 26.34 & 26.94 & 25.46 & 0.4381 & 7.00 \\
\hline Neck, \% & 4.11 & 4.00 & 3.99 & 3.62 & 3.56 & 3.44 & 0.8402 & 27.64 \\
\hline Feet, \% & 4.59 & 4.24 & 4.44 & 4.40 & 3.91 & 4.33 & 0.5520 & 14.62 \\
\hline Head, \% & 3.40 & 3.37 & 3.20 & 3.12 & 2.96 & 3.41 & 0.6637 & 16.82 \\
Fat, \% & 4.53 & 4.51 & 5.63 & 4.74 & 5.04 & 4.59 & 0.8906 & 38.21
\end{tabular}

$\mathrm{CV}$ : coefficient of variation.

\section{References}

Abreu, A., \& Lara, L. (2014). Energia na alimentação de frangos de corte. Avicultura Industrial, 105(7), 44-48.

Ajinomoto (2012). Aminoácidos para nutrição de frangos de corte. São Paulo: Ajinomoto.

Angel, R., \& Sorbara, J. (2014). Why is it important to uderstand substrates if we are to optimize exogenous efficacy? Poultry Science, 93(9), 2375-2379. doi: 10.3382/ps.2013-03869

Baracho, M., Nääs, I., Nascimento, G., Cassiano, J., \& Oliveira, K. (2011). Distribuição da temperatura superficial em aviários. Revista Brasileira de Ciência Avícola, 13(3), 177-182. doi: 10.1590/S1516-635 X2011000300003

Bertechini, A. (2013). Nutrição de monogástricos. Lavras: UFLA.

Demattê, L., Fº., \& Marques, P. (2011). Dinâmica tecnológica da cadeia industrial da avicultura alternativa: mutifuncionalidade, desenvolvimento territorial sustentabilidade. Segurança Alimentar e Nutricional, 18(2), 1-11. doi: 10.20396/ san.v18i2.8634674 
Dourado, L., Barbosa, N., \& Sakomura, N. (2014). Enzimas na nutrição de monogástricos. In N. Sakomura, J. Silva, F. Costa, J. Fernandes, \& L. Hauschild (Eds.), Nutrição de não-ruminantes (pp. 468-481). Jaboticabal: FUNEP.

Ferreira, G., Pinto, M., Garcia, M., Neto, Ponsano, E., Gonçalves, C., Bossolani, I., \& Pereira, A. (2015). Ajuste preciso do nível de energia na dieta de frangos de corte para controle do desempenho e composição lipídica da carne. Ciência Rural, 45(1), 104-110. doi: 10.1590/0103-8478cr20130206

Globoaves (2011). Manual de manejo linha colonial Globoaves. Cascavel: Globoaves Agropecuária Ltda.

Jordão, J., Fo., Silva, J., Costa, F., Albino, L., Melo, T., Lacerda, P.,... Soares, R. (2012). Requirement for maintenance and gain of crude protein for two genotypes of growing quails. Revista Brasileira de Zootecnia, 41(1), 2048-2054. doi: 10.1590/S1516-35982012000900012

Leeson, S., \& Summers, J. D. (2001). Scott's Nutrition of the chicken. (4" edition).

Litz, F., Carvalho, C., Fernandes, E., Martins, J., \& Fagundes, N. (2014). Efeito de diferentes níveis de energia e proteína na ração sobre o desempenho de frangos de corte da linhagem Cobb Avian 48. Veterinária Notícias, 20(1), 52-60. doi: 10.14393/ VTV20N1a2014.23466

Macari, M., \& Maiorka, A. (2017). Fisiologia de aves comerciais. Jaboticabal: FUNEP.

Maiorka, A., Santin, E., Silva, A. V. F., Routman, K. S., Pizauro Jr, J. M., \& Macari, M. (2004). Effect of broiler breeder age on pancreas enzymes activity and digestive tract weight of embryos and chicks. Brazilian
Journal of Poultry Science, 6, 19-22. doi: 10.1590/S1516-635X2004000100003

Melo, A., Fernandes, R., Marinho, J., Arruda, A., Figueiredo, L., \& Fernandes, R. (2016). Relação temperatura e nutrição sobre o desempenho de galinhas poedeiras. PubVet, 10(11), 855-860. doi: 10.22256/ pubvet.v10n11.855-860

Mendes, A. A., \& Komiyama, C. M. (2011). Estratégias de manejo de frangos de corte visando qualidade de carcaça e carne. Revista Brasileira de Zootecnia/Brazilian Journal of Animal Science, 40(Supl. Esp.), 352-357.

Mirzaee, M., Torki, M., \& Habibian, M. (2014). Effects of wheat cultivar, metabolizable energy level and xylanase supplementation to laying hens diet on performance, egg quality traits and selectes blood paramenters. Spanish Journal of Agricultural, 12(4), 1071-1081. doi: 10.5424/sjar/2014124-5929

Moreira, A. S., Santos, M. S. V., Vieira, S. S., Tavares, F. B., \& Manno, M. C. (2012). Desempenho de frangos caipiras alimentados com rações contendo diferentes níveis de energia metabolizável. Arquivo Brasileiro de Medicina Veterinária e Zootecnia, 64(4), 1009-1016.

Oliveira, A., Ferreira, M., Santana, H., Jr., Brito, J., \& Mendes, F. (2015). Caracterização do consumidor de carne de frango em Júlio Borges - Pl. Revista Científica de Produção Animal, 17(2), 129-141. doi: 10. 15528/2176-4158/rcpa.v17n2p129-141

Oliveira, R., Pinheiro, S., Castro, M., Abreu, L., Pires, A., Vieira, D.,... Costa, L. (2016). Lisina digestível na ração de frangos de corte tipo caipira na fase de crescimento. 
Arquivo Brasileiro de Medicina Veterinária e Zootecnia, 68(3), 733-738. doi: 10.15 90/1678-4162-8160

Rosa, E., Kiefer, C., Souza, K., Silva, J., Ozelame, A., Gomes, E., \& Rosa, R. (2014). Níveis de lisina digestível pra frangos de corte tipo caipira de 28 a 56 dias de idade. Revista Brasileira de Saúde e Produção Animal, 15(4), 872-880. doi: 10.1590/s1519-994 02014000400012

Rostagno, H., Albino, T., Donzele, J., Gomes, P., Oliveira, R., Lopes, D.,... Barreto, S. (2011). Tabelas brasileiras para aves e suínos (3a ed.). Viçosa, MG: UFV.

Sakomura, N. K., Longo, F. A., Rabello, C. B. V., Watanabe, K., Pelícia, K., \& Freitas, E. R. (2004). Efeito do nível de energia metabolizável da dieta no desempenho e metabolismo energético de frangos de corte. Revista Brasileira de Zootecnia, 33, 6(Supl. 1), 1758-1767. doi: 10.1590/ S1516-35982004000700014

Sakomura, N., \& Rostagno, H. (2017). Métodos de pesquisa em nutrição de monogástricos (2a ed.). Jaboticabal: FUNEP.

Santos, A., Palheta, I., Santos, R., Nascimento, T., \& Melo, J. (2017). Frequencia e preferência do consumo de carnes bovina, suína e aves por praticantes de exercícios físicos nas academias da cidade de RedençãoPará. Revista Brasileira de Nutrição Esportiva, 11(61), 87-92.
Santos, M., Rabello, C., Pandorfi, H., Torres, T., Santos, P., \& Camelo, L. (2012a). Fatores que interferem no estresse térmico em frangos de corte. Nutritime, 9(3), 17791786.

Santos, M., Vieira, S., Tavares, F., Andrade, P., Manno, M., Costa, H., \& Moreira, A. (2012b). Desempenho, carcaça e cortes de frangos caipira francês Barré (gris barré cou plumé). Archivos de Zootecnia, 61(234), 287-295. doi: 10.4321/s000405922012000200013

Scherer, C., Furlan, A., Martins, E., Scapinello, C., \& Ton, A. (2011). Exigência de energia metabolizável de codornas de corte no perído de 1 a 14 dias de idade. Revista Brasileira de Zootecnia, 40(11), 24962501. doi: 10.1590/S1516-35982011001 100030

Silva, D., \& Queiroz, A. (2002). Análise de alimentos: métodos químicos e biológicos. Viçosa, MG: UFV.

Wasti, S., Sah, N., \& Misha, B. (2020). Impact of heat stress on poultry health and performances, and potential mitigation strategies. Animals, 10(8), 1266. doi: 10. 3390/ani10081266 